THE THIRD MOLLY LEVY LECTURE \title{
LOOKING TO THE FUTURE FROM THE PAST
}

\section{DELIVERED ON MAY 41993}

\section{by J C Beenhakker}

An eponymous lecture is the highest award the South African Society of Physiotherapy can bestow on a member, for outstanding service to the Society and to the Profession. The first recipient of this award, made in 1987, was Molly Levy who steered our Society and Profession from their humble beginnings to the strength in which they find themselves today.

With the dawning of the new South Africa, many changes are expected including reorganisation of the health services and the delivery of health care. We enter this new phase with hope and determination with which to face the unknown challenges. Yet there is some trepidation and uncertainty for what this future holds.

What equips us for the Future?

It is said that traditions keep us connected to our past but

"The Past, seen in the Present, binds us through our Students and New Graduates to the Future. and to those who come after us." 1

We therefore need to go back in time in order to establish our roots, both as regards the South African Society of Physiotherapy as we]l as our profession. For as Helen Hislop said

\section{"A Society and a Profession without a sense of the Past for which it has Respect, lacks Identity and Respect for the Future". 1}

There is much talk, at present, of marketing ourselves and of improving the status of our profession, so that the medical fraternity and the lay public will afford us the respect which we feel is our due.

We need to look back however, and see how our profession started in order to understand our position today. Doctors were always accorded a high status together with the minister of religion, the Mayor and the school teacher, because of their functional importance to society. Nurses, on the other hand, were seen as doctor's helpers and were expected to carry out the doctor's orders.

Our profession was started in Great Britain by nurses in 1895. Many of these British physiotherapists opened training centres in a number of Commonwealth countries, including South Africa, in the twenties and thirties. Small wonder then that we were also seen as the handmaidens of the doctors. Yet we can break out of this mould - Look what the Surgeons have achieved from their humble beginnings as Barbers!

It is important that education should instil a pride in the therapists for the knowledge that they have, much of which is specific to that profession and is theirs. Their decision-making skills and their ability to think critically gives them the right to question and to offer suggestions to others, including the Medical and Dental Fraternity, because their mission should be to

\section{"Give good patient care Not to tip-toe around the physician's ego" Gedan $1973^{2}$}

Fortunately, during the late sixties, there was a move away from performing treatment under prescription of the doctors, who would decide until then on which modalities could be used' and the required dosages. Then greater freedom was obtained when patients were referred to the physiotherapists, who could decide on the treatment to be used. Finally in 1983, we were allowed to practice through consultation and were expected to be able to make a physical diagnosis on which to base our treatment plans. Unfortunately this fact is not generally known and as recently as three weeks ago, a doctor stated in a meeting of the SAMDC that physiotherapists did work under the control of doctors who decided on treatment plans.

It even took our Society a long time to break our bondage of hand maidenship. It was only in 1979, that we took the quantum leap of electing a physiotherapist as President of our Society, rather than a doctor. The first President of the SASP was of course Molly Levy whom we are honouring this evening. Many of the changes in our practice were initiated by our Society but it was Molly Levy, as chairman of our Professional Board, who managed to get them approved by SA Medical and Dental Council.

There is a trend in physiotherapy worldwide for greater independence for practitioners. New rules will soon be promulgated which will give greater autonomy to various professions. Greater freedom does however, bring greater responsibility, and we must ensure that we are prepared to meet these new challenges. Freedom to exercise discretionary judgement in patient care, results in a greater measure of accountability to the profession. The profession as a whole will suffer if this freedom is abused, even if only by the few. For example, overcharging, overservicing and providing false information to the Medical Aids are fairly com- mon complaints. Many physiotherapists believe that the new rules will allow greater freedom to advertise themselves as individuals. However, advertising may only be undertaken in a professional manner and may not be to the détriment of others. It must be remembered that the rules of conduct provide guidelines and directions for appropriate behâviour by practitioners, which protect the interests of the patient and ensure that their rights are upheld. The Mission of the SAMDC and its various Boards, is to promote high ethical standards and to ensure training and practice is appropriate and acceptable.

The South African Society of Physiotherapy on the other hand, protects the interests of its members and aims to ensure that physiotherapists are not discriminated against. We therefore, need to be a strong and united Society in order to fulfill our aspirations. We need to improve communication at all levels and to encourage our members to read their journals and newsletters, which aim to keep them informed of what is happening in the Society and what is being done on their behalf through consultation.

Physiotherapists are working towards first line practitioners, but still function cooperatively within the medical model. Our profession is historically built on scientific lore which has been investigated and accepted by doctors over the years. We are therefore, a medically dominated profession, and are bound to a certain extent by its rules. On the other hand, chiropractors and others who have defined themselves as alternative healers, are mainly independent business men who can engage in direct and successful competition in medicine.

The solution to this problem will not be easy to find. We must however, learn from the past in order to anticipate the future so that we may determine our own destiny.

\section{"We must learn to Think Pro actively Rather than living Reactively".}

We need to be in the forefront to ensure that our education and practice does reflect the changes in the health care needs, and not only react to changes once they have occurred. Perhaps the proposed workshop to be held on Sunday May 9 th will give us some indication to the direction we should be going, and give us a plan for the future. We do know that there will be less emphasis on acute care in high technology institutions, whatever else may be in store.

This is not a new concept and as far back as 1942, Dr Henry Gluckman, then Minister of Health, urged for a unitary health system that would promote the health of the population rather than to treat the diseases once they have occurred.

Continued on page 41 .. 


\section{PHYSICAL AND OCCUPATIONAL THERAPISTS}

\section{Hundreds of positions available immediately, in any state - Florida, Texas, New England . . .}

"MRI found us a wonderful job in a traveling program. Our first assignment was in Las Vegas, Nevada, then we were off to Rhode Island. We wanted to see the United States and get experience. Thanks to MRI, we are doing botb. Everyone bas been so nice to us."

-Annalie Van Zyl and Annelu Van Wyk

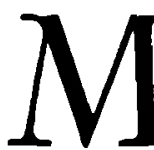

edical Resources International can place you in any specialty in any part of the United States - at $\$ 35,000$ to $\$ 60,000$ a year. Your licensure and credentialing and visa fees are fully paid.

PLUS: we provide a FREE study course and materials to help you pass the state board exams.
We hire in all specialties,including:

- Clinical Coordinatcre and staff positions - Oupatient orthopedics/Sports medicine

- Rehab, including neuro, cardiac, and brain injury

- Acute care a Pediatrics

- Work hardening - Geriatrics

See the U.S. - Apply for one of

our traveling positions:

- Work in a variety of locations

- Company car $\square$ Housing subsidy

- Salaries $\$ 40$ to $\$ 50,000$

- Travel to a new state every three months

Other services:

- FREE Air fare $\mathbf{H o u s i n g}$ assistance

- Medical, life, and professional insurance

Medical Resources InternationalMore Jobs, Better Service

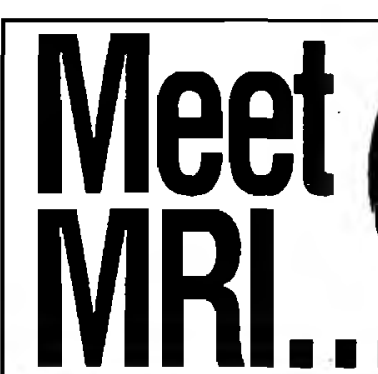

Over 200 health care professionals placed this past year

\section{FREF PRESENTATIONS()N}

"Living and Working in the USA"

Capetown Tygerberg

- Pretoria Durban

- Johannesburg

- Bloemfontein

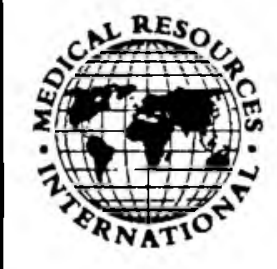

Presentations to be beld in late September. Please call for exact date and time.

\section{CALL US COLLECT 5154724018}

For presentation dates and times Offices in Australia, Ū.K., Holland, Poland, Philippines, and U.S.A.

Medical Resources International, Ltd. 101 N. Main St., Suite 202, Fairfield, IA 52556 U.S.A. • Fax (515) 472-1897 


\section{.Continued from page 39}

Our present health administrators are promoting affordable, equitable and available health services for all with the emphasis on preventative health - fifty-one years after this idea was first mooted, and unfortunately not accepted by the government of the day.

Preventive Health

Professor Nancy Watts in 1983 told a story to illustrate prevention which I would like to retell. It is a story of a man, standing on the bank of a river, who keeps on diving in to rescue drowning men as they are being swept past. No sooner is one safely brought to shore, when another cry for help is heard. When the rescuer is asked what he is doing, he gasps that the drowning men are coming down river so fast, that he does not have a moment to rush upstream to see what is causing the men to fall into the river in the first place. We as health care workers need to make time to find the cause of health problems, and suggest ways of preventing these so that less money will need to be spent on treatment of disease and more will be available for preventative and promotive health care.

Our undergraduate education, over the decades, has adapted to changes as they occurred, although many of us would agree that our training is not meeting most of the health care needs of the country. Most of us are aware that our services are urgently needed in those areas with least access to health care. It is however, of little value adding the odd module on community health and preventive care to an already overloaded curriculum, in the hope that the needs will be met. If we expect our graduates to work in isolated rural communities, then we must give them the means to do this, and the health services must support them once they are there. The Universities do, on the whole, strive to give their students the tools which they will need to meet present and future demands. It is hoped that the graduates will make use of the cognitive and decision-making skills which they have acquired, in order to cope with the reality of practice once they have graduated. No new graduate can be expected to be competent in all areas of clinical practice, as neither in deed can an experienced practitioner lay claim to this ability. It is expected that these new physiotherapists will improve their psychomotor skills when working full-time, with some clinical support, following graduation. Perhaps there is some merit in an internship period during which the recent graduate may also be instructed in management and legal matters.

Now that specialisation has become a reality, we need to consider a speciality in Community and Primary Health Care.
This will require a group of concerned physiotherapists to undertake this task, as has been done by members of Special Interest Groups for their specialities. We should not be asking the $S$ A Society of Physiotherapy to set up another ad hoc committee to investigate the matter. Rather, those of us who feel strongly that this is the road we should be following, should volunteer to undertake the task.

Finally we need to preserve the heritage which was handed aown to us by our Founder Members whose enthusiasm and dedication established the South AFrican Society of Physiotherapy. But those of us who received the legacy from these pioneers, need to hand it down to those who will follow us.

\section{As John F Kennedy said}

"It is the Task of our Times and in our Generation to hand down undiminished to those who come after us, what was handed down to us by those who went before".

Many members of the profession have supported their Society and have given of their time and money to enable the SASP to grow in strength for those who follow. Less thought was given by these members as to how the Society would benefit them, but rather how they could be of service to their professional association. For the society to be economically viable and well managed to meet the needs of its members, we require the participation of many more physiotherapists in the affairs of the profession which extend beyond patient care. We must identify and nurture those physiotherapists who are willing to be an active part of the Society of physiotherapy. They do need assistance and encouragement to achieve their full potential. We all know the saying that if you give a man a fish you feed him for one day. But if you teach him how to fish, you feed him for life. We therefore need to give those who are willing to serve, at Branch and special interest group level, our help so that they may become strong leaders and carry on the good work of the profession. Then us oldies will be happy to step back and hand over the reins to the future kingpins of the profession.

\section{In conclusion}

I have looked back at some of the milestones of our past in the hope that they may lead us to the signposts of the future. The reality of the future can be determined by our own foresight and vision, and should not depend on what others think we need to do or be. Health care for the majority of the citizens of South Africa should be our mission, and unless we learn to think more globally, there is the danger that others will step into the breach. We are so concerned with protecting our scope of practice, that the means of changing our thrust to meet changing health needs may be neglected. I trust that the coming Congress will focus on the challenges facing us and give us direction to prepare for the 21st Century.

We have obviously gained a great deal from our early Pioneers, whoseclear vision was their strength. We have also learned through trial and error but should take care of not re-inventing the wheel, when we set our goals for the future.

As Mr Harry Oppenheimer said

"If we are wise, we will make every effort to learn from other people's experience. That is a process which is much easier and very much less painful."

Let us learn from this collective experience and wisdom and to channel our energies into strengthening the Society and making our profession truly great.

\section{References}

1. Hislop JH. The not-so-impossible dream. Physical Therapy 1975;55(10)1069-1080.

2. Gedan S. Critical Incidents in Nursing 1093; Ed. Bermosk and Corsini, Philadelphia. WB Saunders Company.

3. Watts NT. The Privilege of Choice. Physical Therapy 1983;63(11)1802-1808.

\section{RESPITE CARE CENTRE}

A new service, providing temporary accommodation for the Physically Disabled has opened its doors to a "Half-way House" in the Transvaal. Accommodation can be offered to seven disabled persons, who are in reasonable health and independence for a period of one day up to three months.

The centre, situated in Johannesburg, will cater for the following needs

- the need to be attended to by an Orthotist

- a student attending a short training course

- discharges from hospital too early to be independent at home or with no immediate sanctuary. It is aimed to enable these disabled persons to live full, meaningful lives within the community

- relief to care-givers (family or friend) by providing accommodation for the disabled family member allowing the care-giver to enjoy a short break or longer holiday

- abandoned by the death of the care-giver or next of kin

- the disabled person still needing physiotherapy or occupational therapy between full hospital care and returning to the community.

Costs - Fees will be determined on each applicant's circumstances. This non-profit making service will depend on fundraising and donations in addition to fees.

For further information contact

Mr Paul Jạckson (011) 888-6122, 646-8331

Matron Lily Krause (011) 888-6122 